\title{
Article 9 and the History of Japan's Judiciary: Examining Its Likeness to American and German Courts
}

\author{
Yuichiro TSUJI*
}

After the Abe Administration's interpretation of Article 9 of the Japanese Constitution in 2014, questions have been raised regarding whether the likeness of the Japanese Supreme Court is closer to U.S. or German constitutional courts.

The Japanese administration has long held the view that Article 9 of the Japanese Constitution permitted only individual defense, not collective defense power. The Abe cabinet changed the head of the Cabinet Legislation Bureau in 2013 and made an official announcement concerning its interpretation of Article 9 of the Japanese Constitution in 2014. The Self-Defense Force (Jieitai, SDF) is now able to exercise collective defense power. This change did not involve an amendment to the Japanese Constitution.

The National Police Reserve (Keisatsu Yobitai), the predecessor of the Self-Defense Force, was established just before Japan gained its independence in 1952 by signing the San Francisco Peace Treaty. Mosaburo Suzuki, head of the Japanese Socialist Party, brought suit directly to the Supreme Court. In 1952, the Supreme Court dismissed his suit on the grounds that he lacked standing because he was only the head of a political party and no injury was in fact caused by the establishment of the National Police Reserve; the court announced its position as a U.S.-type judiciary. Unlike the U.S. Constitution, judicial review was stipulated

* Yuichiro TSUJI, Associate Professor at the Graduate School of Humanities and Social Sciences (legal major and international regional studies major) at the University of Tsukuba. J.S.D University of California, Berkeley (2006). LL.M. University of California, Berkeley (2005). Master of Law, Kyoto University. The preceding discussion of this paper was published as Constitutional Amendment, 37 Nanzan Review of American Studies 51 (2015), and as Constitutional Law Court in Japan, 66 Tsukuba Journal of Law and Politics 65 (2016).

This paper was modified after presentation international symposium on Thursday and Friday, 19th \& 20th May 2016 for Asian Perspectives on Legal Globalization 13th Asian Law Institute Conference at Peking University Law School, People's Republic of China. I thank all the people who worked and attended this symposium. 
in Article 81 of the Japanese Constitution, but the terms of the case and controversy were not included. The dispute on the law was written only in the Japanese Court Act.

Almost 70 years after the Japanese Constitution was promulgated in 1947, some Japanese constitutional scholars have been considering why the Japanese Supreme Court has not exercised its judicial power in the same manner as the U.S. Supreme Court. The Japanese Supreme Court has only ruled about 10 cases as unconstitutional on their face, while 12 cases were declared unconstitutional on application. Japanese scholars in the past as well as today have discussed the prospect of establishing a constitutional law court in Japan.

In this paper, I will first describe the history of the draft of the Japanese Constitution, and the reasons why the Japanese Constitution did not include the terms of the case and controversy as in Article III of the U.S. Constitution.

Second, the possibility of the birth of a German-type Constitutional Court in Japan is reviewed. By simply amending the Court Act, the Japanese judiciary could become a German-type constitutional court. Alternatively, if we believe the core responsibility of the judiciary according to the Japanese Constitution is to adjudicate adversarial arguments, to adopt a German-type constitutional court would entail amending the Japanese Constitution.

Third, I will introduce the current defense and security statutes against which some Japanese constitutional law scholars are.

Lastly, I review several perspectives of Japanese constitutional law scholars regarding the peace and defense statutes passed in 2015.

\section{History of Article 9}

\section{The History of Article 9 of the Japanese Constitution}

The Liberal Democratic Party (Jiyu Minshu Tou, LDP) has criticized the Japanese Constitution because the party felt that the General Headquarters of the Supreme Commander for the Allied Powers (GHQ/SCAP), forced the Japanese government to adopt it as the new Japanese Constitution in $1946 .^{1}$

1 The current Constitution of Japan was promulgated on November 3, 1946 and took effect on March 3, 1947. 
The drafting history of the Japanese Constitution occurred in two steps. The first step was from August 14, 1945 to February 13, 1946 when Japan accepted the Potsdam Declaration in the MacArthur note. The second stage was from the date of the MacArthur note through November $3,1947 .^{2}$

The Japanese government accepted the Potsdam Declaration on August 14, 1945 after two atomic bombs were dropped on Hiroshima and Nagasaki on August 6 and 9. In classes on Japanese Constitutional Law, students are taught that the Potsdam Declaration required the Japanese government to surrender its armed forces and establish a peaceful and responsible government according to the will of the Japanese people. Government officials did not understand its actual meaning at that time. ${ }^{3}$

On October 4, the Supreme Commander for the Allied Powers, Douglas MacArthur, issued the "Civil Liberties Directive," which abolished the Maintenance of the Public Order Act (Chian Iji Hou), acquitted political criminals, legalized criticism of the Emperor, and repealed the thought police. Giving up on the pursuit of these issues, the Higashi Kuninomiya Cabinet resigned on October 5, 1945.

On October 11, MacArthur suggested to the new Prime Minister, Kijuro Shidehara, that the Imperial Constitution (Meiji Constitution) be liberalized. Shidehara established the Constitutional Problem Investigation Committee (Kenpo Mondai Chosa Iinnkai, the Matsumoto Committee) to draft a new Constitution. ${ }^{4}$ Its Chairman, Joji Matsumoto, drafted

2 The origin and history of the Japanese Constitution in English. Birth of the Constitution of Japan [English]. < http://www.ndl.go.jp/constitution/e/index.html >. (last visited on February 26, 2016).

JOHN HALEY, THE SPIRIT OF JAPANESE LAW 177 (University of Georgia Press 2006).

Hideo Tanaka, A History of the Constitution of Japan of 1946, HIDEO TANAKA \& MALCOM SMITH, THE JAPANESE LEGAL SYSTEM 653-(University ot Tokyo Press 1976).

Lawrence Beer, Peace in Theory and Practice under Article 9 of Japan's Constitution, 81 Marquette Law Review 81 (1998).

3 TATSUO SATO, NIHONKOKU KENPO SEIRITSUSI, VOL. I [The History of the Constitution of Japan, Vol. I] 8-31 (Yuhikaku 1962) [hereinafter KENPO SEIRITSUSI VOL.I ]. The serious concern of Japanese government was to maintain "Kokutai."

NOBUYOSHI ASHIBE, KENPO [Constitution] 28 (Iwanami Shoten 2015) [hereinafter ASHIBE $K E N P O]$. This book is currently being edited by Prof. Kazuyuki Takahashi as Prof. Ashibe passed away in 1999.

4 KENPO SEIRITSUSI VOL.I, supra note 3 at 252-374.

The advisors of the Matsumoto Committee were Tatsukichi Minobe, Toru Simizu, and Junji Nomura who were constitutional and administrative scholars. The members were Toshiro Irie and Isao Sato. Drafting a new constitution was not the original aim of this committee. 
a document called the Gist of the Revision of the Constitution. ${ }^{5}$ On February 1, 1946, this draft was published by the Mainichi Newspaper. Surprised by its old-fashioned nature, ${ }^{6}$ MacArthur ordered the establishment of a task force to draft a new Constitution on February 3. On February 8, when the government's drafts of the new Constitution were rejected, a draft by the GHQ in English was submitted to Joji Matsumoto. When MacArthur ordered General Courtney Whitney to draft a new Constitution on February 2-3, he noted three important points that were to be considered in the new Constitution. These points are known as the MacArthur note. ${ }^{7}$

The first point was that the emperor "was at the head of the state. His succession is dynastic. His duties and powers will be exercised in accordance with the Constitution and responsive to the basic will of the people as provided therein."

Second, "[w]ar as a sovereign right of the nation is abolished. Japan renounces it as an instrumentality for settling its disputes and even for preserving its own security. It relies upon the higher ideals that are now stirring the world for its defense and its protection. No Japanese Army, Navy, or Air Force will ever be authorized and no rights of belligerency will ever be conferred upon any Japanese force."

Third, "[t]he feudal system of Japan will cease. No rights of peerage except those of the Imperial Family will extend beyond the lives of those now existent. No patent of nobility will from this time forth embody within itself any National or Civic power of government."

The Liberal Democratic Party was established in 1955 by merging the Liberal Party (Jiyu Tou) and the Japanese Democratic Party (Nihon Minshu Tou). Its party platform was to create its own constitution. Those who are against the current Japanese Constitution think

5 This committee put forth two drafts.

TATSUO SATO, NIHONKOKU KENPO SEIRITSUSI, VOL. II [The History of the Constitution of Japan, Vol. II] 485-646 (Yuhikaku 1974) [hereinafter KENPO SEIRITSUSI VOL. II ].

6 This Gist of the Revision of the Constitution included four principles. First, the basic principle expressing the Emperor's sovereignty was not changed. Second, the power of the parliament was expanded, thus diminishing the control of the Emperor. Third, the responsibilities of the Ministries were expanded to cover all national politics. Fourth, the protection of rights of the people was strengthened.

7 KENZO TAKAYANAGI, ICHIRO OHTOMO, and HIDEO TANAKA, NIHONKOKU KENPO SEITEI NO KATEI [The Making of the Constitution of Japan, Vol. I Documents] 99 (Yuhikaku 1995) [hereinafter TAKAYANAGI ET.AL VOL.I ]. 
that the process was undemocratic and that it was imposed by the GHQ. ${ }^{8}$ The Japanese constitutional research opposes the LDP's position for the following reasons. ${ }^{9}$

First, not only the Gist of the Revision of the Constitution but also other drafts of the constitution were introduced by constitutional scholars from the end of 1945 through the beginning of $1946 .{ }^{10}$ An example is the "Outline of the Constitution Draft," which was submitted by the Constitution Investigation Association (Kenpo Kenkyukai); this organization was established upon the suggestion of Iwasaburo Takano and Anzo Suzuki in 1945. It was not a governmental draft but purely a private draft that was more advanced than the current constitution. The sovereignty of the people, a list of fundamental rights, and a list of social rights were included. It was translated into English and submitted to the GHQ. ${ }^{11}$

Second, research on constitutional drafts began in 1945. The current constitution had a list of inalienable rights and included the principle of the people's sovereignty, which is a universal principle around the world. ${ }^{12}$

The GHQ and the Japanese government had several meetings and finished their draft on March 2 (their project was called the March 2 Draft). The Japanese government brought the draft to the GHQ. The "Outline of a Draft for a Revised Constitution" was completed on March 6. The "Draft for a Revised Constitution" (March 6 Draft) was published on March 7 in newspaper. The Japanese people were surprised by this very democratic draft but generally welcomed it. ${ }^{13}$

The general election of the Imperial Diet under universal suffrage occurred on April

8 MAKOTO OHISHI, NIHON KOKU KENPOU SI [History of the Japanese Constitution] 355 (Yuhikaku 2005) [hereinafter OHISHI]. Prof. Ohishi believes that the GHQ imposed the constitution on the Japanese government. According to his analysis, the MacArthur note and his draft form the model for Article 9 and became grounds for the SDF.

9 ASHIBE KENPO, supra note 3 at 25.

10 KENPO SEIRITSUSI VOL. II, supra note 5 at 733-884.

TOSHIHIKO NONAKA, MUTSUO NAKAMURA, KAZUYUKI TAKAHASHI, and KATSUTOSHI TAKAMI, KENPO I [Constitution I] 56 (Yuhikaku 2012) [hereinafter NONAKA ET AL.I].

11 Iwasaburo Takano was not satisfied with The Outline of the Constitution Draft and separately drafted his own republican constitution that stated the head of the state was to be the president. KENPO SEIRITSUSI VOL. II, supra note 5 at 784-860.

12 KOJI SATO, KENPO [Constitution] 66 (Seibundo 2011) [hereinafter KOJI SATO ].

13 ASHIBE KENPO, supra note 3 at 28-29.

TATSUO SATO, NIHONKOKU KENPO SEIRITSUSI, VOL. III [The History of the Constitution of Japan, Vol. III] 200-209 (Yuhikaku 1974) [hereinafter KENPO SEIRITSUSI VOL. III]. 
10, 1946. ${ }^{14}$ This April election was also involved a vote by the people to approve the a "Draft for a Revised Constitution" (March 6 Draft). ${ }^{15}$

After the general election, "Kenpo Kaisei Soan" (April 17 Draft, Final Draft of Japanese Constitution) was published. It was submitted to the Privy Council. ${ }^{16}$ In accordance with Article $73^{17}$ for the amendment of the Meiji Constitution, it was approved in the House of Representatives on August 24 and the House of the Peers on October $6 .^{18}$

\section{Drafting history and the Self-Defense Force}

The drafting history is not conclusive evidence for the interpretation of the Japanese Constitution but it might influence the interpretation of a particular Article of the Japanese Constitution.

Article 9 of the Draft for a Revised Constitution had no second paragraph in the "Kenpo Kaisei Soan" (April 17 Draft). An important modification in the second paragraph of Article 9 was made during a discussion in the Imperial Diet. In August, in a subcommittee meeting of the Committee on the Bill for Revision of the Imperial Constitution in the House of Representatives, Chairman Hitoshi Ashida added the text, "to accomplish the aim of the preceding paragraph" in the second paragraph of Article $9 .{ }^{19}$

14 Public officials were purged from public service on January 4, 1946.

15 The U.S. State Department was not in favor of this proposal and instead argued that a stronger executive branch should be established.

16 KENPO SEIRITSUSI VOL. III, supra note 13 at 349-432.

Prime Minister Kijuro Shidehara introduced the draft at a meeting of the Privy Council in March. Dainihon Teikoku Kenpo [Meiji Kenpo, Meiji Constitution], Art. 73. When it becomes necessary in the future to amend the provisions of the present Constitution, a draft to that effect shall be submitted to the Imperial Diet by Imperial Order. (2) In the above case, neither house can initiate the debate unless two thirds or more of all Members are present, and no amendment can be passed unless a majority of two thirds or more of the Members present is obtained.

17 Dainihon Teikoku Kenpo [Meiji Constitution, Constitution of the Empire of Japan], Art. 73.

18 OHISHI, supra note 8 at 356-357. Prof. Ohishi believes that the drafting history shows legal defects in the establishment of the Japanese Constitution.

19 TATSUO SATO, NIHONKOKU KENPO SEIRITSUSI, VOL. IV [The History of the Constitution of Japan, Vol. IV] 588-598,788-794,857-858 (Yuhikaku 1994). Tatsuo Sato took detailed note for Article 9 draft [hereinafter KENPO SEIRITSUSI VOL. IV]

Nihonkoku Kenpo [Kenpo][Constitution], Art. 9. Aspiring to international peace based on justice and order, the Japanese people forever renounce war as a sovereign right of the nation and the threat or use of force as means of settling international disputes. In order to accomplish the aim of the preceding paragraph, land, sea, and air forces, as well as other war potential, will never be maintained. The right of the belligerency of the state will not be recognized. 
Prime minister Shigeru Yoshida mentioned in the plenary session in June, 1945 that paragraph 1 waiver war even for self- defense because war has been occurred in the name of self-defense and Japan could not have armed force.

In a meeting of the Far Eastern Commission (FEC), the Chinese delegation pointed out that this text might justify the formation of a Japanese army. ${ }^{20}$ Thus, the House of Peers added Article $66,{ }^{21}$ the civilian requirement.

The amendment by Ashida provided justification for the government to maintain a minimum ability to defend itself with a Self-Defense Force (Jieitai). ${ }^{22}$ Language to this effect was added by the Imperial Parliament.

\section{The Cabinet Legislation Bureau and the students of Anzo Suzuki}

The Cabinet Legislation Bureau (Naikaku Housei Kyoku, CLB), was originally formed under the Meiji Constitution. It was formerly under the Ministry of Justice but is now under the Cabinet. Its most senior official is not a minister, but rather a chief. The CLB monitors bills submitted by the ministries and has been charged with the public interpretation of the Japanese Constitution since the Japanese Constitution was ratified. ${ }^{23}$ There is no mention of the CLB in the Japanese Constitution.

Japanese governmental interpretation endorsed the power of self-defense as a power of sovereignty in the famous Sunagawa case. ${ }^{24}$ The CLB explained that individual defense and

20 KENPO SEIRITSUSI VOL. IV, supra note 19 at 918-931.

RICHARD FINN, WINNERS IN PEACE: MACARTHUR, YOSHIDA AND POSTWAR JAPAN 115(Berkeley, University of California Press 1992).

21 Nihonkoku Kenpo [Kenpo][Constitution], Art. 66(2). The Prime Minister and other Ministers of State must be civilians.

22 NONAKA ET AL. I, supra note 10 at 164.

KOJI SATO, supra note 12 at 93.

KENPO SEIRITSUSI VOL. IV, supra note 19 at 789 -.

23 MASAHIRO SAKATA, SEIHU NO KENPO KAISHAKU [Constitutional Interpretation by the Government] 1-6 (Yuhikaku 2013) [hereinafter SAKATA].

THE SPIRIT OF JAPANESE LAW, supra note 2 at 35.

24 Saiko Saibansho [Sup. Ct] Dec. 16, 1959, Showa 34(a) no. 710, 13 Saiko Saibansho Keiji Hanreishu [Keishu] 3225.

KOJI SATO, supra note 12 at 94.

Yuichiro Tsuji, Constitutional Law Court in Japan, 66 Tsukuba Journal Law and Politics 65,84 (2016). 
collective defense powers were noted in Article $51^{25}$ of the Charters of the United Nations. The Japanese Constitution only permitted individual defense power as collective defense power was unconstitutional because it could involve Japan in unnecessary disputes. The CLB divided "war" into invasive and defensive war. The term "renounce war" in the first paragraph of Article 9 meant that the Japanese government waived invasive war and the wording "[i]n order to accomplish the aim of the preceding paragraph" meant in order to accomplish the waiver of invasive war $^{26}$ while permitting the Japanese government to maintain a minimum ability to defend itself. These were the constitutional interpretations regarding the Self-Defense Force.

The students of Anzo Suzuki became professors of constitutional law at several universities throughout Japan. ${ }^{27}$ They have had different interpretations of Article 9. Most of them argued that "renounce" in paragraph one of Article 9 meant all war was waived. Wars occur in history as a means to solve international disputes. Both defense and invasive war should be prohibited. Some argued that motivation for war and "the threat or use of force" were too difficult to divide into either self-defense or invasive or aggressive wars. It was too difficult to follow the Pact of Paris of $1928 .^{28}$

These scholars thought that the Charter of the United Nations prohibited all war other than that which resulted from self-defense. Facing aggressive or invasive war, the U.N. Armed Forces was organized to protect invaded nations but Article 9 prohibited the Japanese government from participating in the U.N. Armed Forces because Japan lost World War II.

This idea follows the principle of collective security under the U.N. They explained that the Japanese government's punishment for World War II was the inability for that

25 Article 51 of the Charter of the United Nations states, "Nothing in the present Charter shall impair the inherent right of individual or collective self-defence if an armed attack occurs against a Member of the United Nations, until the Security Council has taken measures necessary to maintain international peace and security. Measures taken by Members in the exercise of this right of selfdefence shall be immediately reported to the Security Council and shall not in any way affect the authority and responsibility of the Security Council under the present Charter to take at any time such action as it deems necessary in order to maintain or restore international peace and security."

26 Prof. Koji Sato holds the position that this interpretation is in line with the MacArthur draft and the subsequent draft submitted in the Imperial Diet.

KOJI SATO, supra note 12 at 94.

27 Association for the Study of Constitutional Theory, Kenpo Riron Kenkyu Kai was established in 1964. See http://kenriken.jp.net/ (last visited on February 18, 2016).

28 NONAKA ET. AL. VOL.I, supra note 10 at 165. 
government to participate in the U.N. Armed Forces. Thus, some Japanese constitutional scholars criticized the pre-2014 public interpretation.

They argued that there were no constitutional provisions other than Article $66^{29}$ that permitted maintaining an army. The preamble to the Japanese Constitution ${ }^{30}$ expects the collective security provided by the U.N. Any interpretation permitting invasive war is contrary to the idea of pacifism set forth in the preamble.

Yasuo Hasebe proposed another interpretation that follows the pre-2014 public interpretation of the CLB. ${ }^{31} \mathrm{He}$ argued that there are several ideas regarding methods to keep peace among the Japanese people. It is nonsense for him to think that there is no way for Japanese government to protect its people against attacks from foreign nations. The power to protect itself is only possible under the current Japanese Constitution. Regardless, the majority of Japanese constitutional law scholars are against the Abe cabinet decision of 2014 to endorse collective defense power without amending the constitution (Kaishaku Kaiken).

The history of drafting Article 9 shows the importance of Article 66, which contains civilian provisions. Regarding Article 66, Katsutoshi Takami noted an important fact that during the drafting period from 1945 to 1946, a Japanese army did not exist. ${ }^{32}$ The proposal to provide an army of force in the new constitution meant that the Japanese government had to establish a new army at that time. Takami suggested that within the Matstumoto Committee there were camps for and against the provision of an army. The camp against the provision of an army won and this led to the current interpretational disputes of Article $9 .^{33}$

29 Nihonkoku Kenpo [Kenpo][Constitution], Art. 66(2).

30 See id. preamble, "trusting in the justice and faith of the peace-loving peoples of the world." NONAKA ET.AL.VOL.I, supra note 10 at 168-73.

31 YASUO HASEBE, KENPO TO HEIWA TO TOINAOSU [Question Again the Constitution and Peace] 29-42. (Chikumashinsho 2004). YASUO HASEBE, KENPO [Constitution] 69 (Sinseisha 2014).

32 KATSUTOSHI TAKAMI, [KENPO 9] Jou Kaishaku Tairitsu no Genryu [Origin and Development of Conflict of Interpretation of Article 9], Institute of Comparative Law of Waseda University, Nihon Hou No Kokusai Teki Bunmyaku [International Context Of Japanese Law] 258 (Waseda University 2005).

33 KOJI TONAMI, Takami Houkoku heno Komento [Comment to the Takami Report], Institute of Comparative Law of Waseda University, Nihon Hou No Kokusai Teki Bunmyaku [International Context of Japanese Law] 279 (Waseda University 2005). 


\section{National Security Council under the Abe Cabinet}

The first Abe Administration planned to establish a National Security Council (NSC) but Abe resigned in August 2007. After regaining power in December 2012 from the Democratic Party, he issued the Proactive Contribution to Peace (Sekkyoku teki Heiwa shugi) ${ }^{34}$ and changed the prior CLB's public interpretation of the Japanese Constitution. According to Abe, cooperation with other governments is vital to Japanese defense and security. Abe decided that a collective defense power should be established without amending the Japanese Constitution (Kaishaku Kaiken).

In the NSC, four members of the Cabinet were summoned to work on the issue: the Prime Minister, the Minister of Defense, the Minister of Foreign Affairs, and the Chief Cabinet Secretary. ${ }^{35}$ The NSC follows the American NSC, and the cabinet is in charge of the diplomatic and national and security strategy (NSS). ${ }^{36}$ These four members weighed the issues surrounding the reorganization of the United States military stationed in Japan, the relationship with China, the North Korean missile issue, and territorial issues. Another five ministers were summoned to design the fundamental policy for national defense, the basic defense program, and responses to armed attack situations. The NSC office is set up in the Cabinet Secretariat. ${ }^{37}$

This move was analyzed in light of the Algerian hostage crisis of January 2013. The Asahi Shimbun ${ }^{38}$ and The Tokyo Shimbun ${ }^{39}$ published articles opining that the establishment of the NSC was too hasty at that time and that existing organizations and procedures would easily handle disasters and crisis situations.

34 Ministry of Defense, The Proactive Contribution to Peace. Available at http://www.mofa.go.jp/ policy/security/ (last visited on February 18, 2016).

35 Ministry of Defense, Information on the National Security Council. Available at http://www.mofa. go.jp/fp/nsp/pagelwe_000080.html (last visited on February 18, 2016).

36 Ministry of Defense, Information on the National Security Strategy. Available at http://www.mofa. go.jp/fp/nsp/pagelwe_000081.html (last visited on February 18, 2016).

37 Id.

38 Jieitai no Houjin Kyushutsu Genba ni Nandai Buki Siyou Dokomade [Difficult Problems for the SDF Rescue Mission for Japanese, the Standards for Weapon Use], The Asahi Shimbun, (February 20, 2015). Available at

http://www.asahi.com/articles/ASH2K0624H2JUTFK00S.html (last visited on December 26, 2015).

39 Editorial, Houjin Yuso Minaoshi [Review of Japanese Transportation], The Tokyo Shimbun, (February 4, 2013). 
The Abe Administration might have considered the NSC to be a vehicle of civilian control. This might be true if we understand that the core of civilian control in Article 66(2) is legislation. Nonetheless, accountability by the NSC would still be questioned if public access was too primitive.

In 2015, the following new examination agenda items were added: measures against Sonritsu Kiki Jitai, measures against Juyo Eikyo Jitai, and international peace collaboration missions. The NSC needed to deliberate on determinations or changes to the implementation programs for securing safety, on Kaketsuke Keigo for international peace collaboration missions, and on sending SDF officers to assist with other countries for U.N. peace-keeping operations. These issues will be discussed in Chapter III.

\section{Japanese constitutional law scholars' theories on Article 9}

Before the 2014 Abe Cabinet decision, some constitutional scholars who were students of Anzo Suzuki thought that the SDF could be considered an "army" as prohibited by Article 9. They felt that expanding the scope and power of the SDF was unconstitutional. Article 9 was to be amended if the government strengthened the current level of the SDF.

Kazuyuki Takahashi ${ }^{40}$ explains that Article 9 is balanced with constitutionalism. He does not believe that Article 9 is simply an advisory provision with no legal teeth. If Article 9 is a political indicator with no legal force, ${ }^{41}$ then it is powerless even in the political sphere. Using the political question doctrine, the court can avoid determining the constitutionality of the SDF. Takahashi added that the anti-democratic nature of the political question doctrine should provide standing for a plaintiff asking for a remedy but the case was dismissed. ${ }^{42}$

40 KAZYUKI TAKAHASHI, RIKKENSHUGI TO NIHONKOKUKENPO [Constitutionalism and the Constitution of Japan] 63 (Yuhikaku 2013).

41 MASAMI ITO, KENPO [Constitution] 168-99 (Koubundou 1995). Prof. Ito explains that Article 9 is a political norm not a legal norm.

42 There is controversy over the scope of the political question doctrine in Japan. ISAO SATO, KENPO KAISHAKU NO SHOMONDAI [Constitutional Interpretation Problems] 136-137 (Yuhikaku 1962). Prof. Isao Sato noted that there was no specific standard for "clearly obvious unconstitutionality or invalidity" in the Sunagawa case. Isao Sato argued that using the political question doctrine had no justification in the Sunagawa decision. He imagined that the Supreme Court might have wanted to put limitations on the political question doctrine. Isao Sato supports a narrow scope for the political question doctrine. This argument will be analyzed in Yuichiro Tsuji's upcoming 
Yasuaki Ohnuma ${ }^{43}$ expects that a world government will emerge in the future but that the constitutional issue should not be based on an idealistic view of a world government. Under the current sovereign governmental regime, any U.N. resolution has legitimacy worldwide. An action by the U.N. is similar to an international policing action. The Japanese SDF may operate under a directive of the U.N. when it performs police actions but not when it performs military actions. Asaho Mizushima also discussed the nature of police actions. ${ }^{44}$

Since the Japanese Constitution was promulgated, judicial review in Japan has been influenced by U.S. and European constitutional studies and has developed through several cases regarding the constitutionality of the SDF.

\section{The Constitutional Court in Japan}

Compared to the U.S. Constitution, there have been few unconstitutional decisions in the Japanese Supreme Court since the Japanese Constitution was ratified. ${ }^{45}$ One approach was to establish a Constitutional Court with exclusive jurisdiction over constitutional issues in the Japanese judiciary.

In Germany after World War II, the German Federal Constitutional Court (Bundesvefassungsgericht, BVerfG) was established under the Basic Law ${ }^{46}$ and is the only court that may declare statutes unconstitutional under the Basic Law. This may be

Vote Value Disparity and Judicial Review (2016).

Taisuke Kamata, Adjudication and the Governing Process; Political Questions and Legislative Discretion, PERCY LUNEY AND KAZUYUKI TAKAHASHI, JAPANESE CONSTITUTIONAL LAW 156-157 (University of Tokyo Press 1993).

43 Yasuaki Ohnuma, Comment Regarding the Reality of the International Society and the Establishment of International Peace During the Commission on the Constitution, House of Councilors. Available at http://www.kenpoushinsa.sangiin.go.jp/kenpou/houkokusyo/ hatugen/03_05_05_01.html (last visited on February 18, 2016).

44 Asaho Mizushima, Comment Regarding Reality of the International Society and the Establishment of International Peace During the Commission on the Constitution, House of Councilors. Available at http://www.kenpoushinsa.sangiin.go.jp/kenpou/houkokusyo/hatugen/03_05_05_01.html (last visited on February 18, 2016). Prof. Mizushima argues that Japan must observe the international rule of law independent of the United States.

45 MASAMI ITO, SAIBANKAN TO GAKUSHA NO AIDA [Between Justice and Scholar] 106-137 (Yuhikaku 1993).

Tsuji, supra note 24 at 86.

46 Grundgesetz fur Die Bundersrepubrik Deutschland [Grundgesetz] [GG] [Basic Law], May 23, 1949, NGNI.I (Ger). 
accomplished in various ways such as abstract judicial review. Only a limited group of applicants may file applications for an abstract review of a statute. ${ }^{47}$

These proceedings involve the review of a statute's constitutionality under all relevant aspects regardless of the specific legal dispute or whether or not the applicant is affected. The proceedings are regulated under Article 93 of the Basic Law ${ }^{48}$ and under specific articles of the Federal Constitutional Court Act. ${ }^{49}$

Proceedings of this type may be recognized by their "BvF" file reference. Generally speaking, only very few proceedings for the judicial review of statutes are initiated. However, almost all of these proceedings are of major importance.

A specific judicial review of statutes can also be conducted. Only the Federal Constitutional Court is competent to determine the constitutionality of laws. If another court considers a law to be unconstitutional and the validity of said law is material to the decision, it suspends the proceedings and refers the matter to the Federal Constitutional Court for a determination.

This type of proceeding is therefore also known as judicial referral and is regulated under the Basic Law ${ }^{50}$ and the Federal Constitutional Court Act. ${ }^{51}$ These proceedings can be recognized by their "BvL" file reference.

A constitutional complaint may be lodged by any natural or legal person if they believe that their fundamental rights ${ }^{52}$ or specific rights that are equivalent to fundamental rights ${ }^{53}$ have been violated by the German public authority.

A constitutional complaint makes it possible for citizens to assert their freedoms as guaranteed under the constitution vis-à-vis the state.

47 More information on the abstract review of statutes is available at http://www. bundesverfassungsgericht.de/EN/Verfahren/Wichtige-Verfahrensarten/Abstrakte-Normenkontrolle/ abstrakte-normenkontrolle_node.html

(last visited on February 18, 2016). See also, Rudolf Streinz, The Role of the German Federal Constitutional Court, Law and Politics, 31 Ritsumeikan Law Review 95 (2014).

48 Grundgesetz, [GG] [Constitution] Art. 93(1) (Ger).

49 Bundesverfassungsgerichtsgesetz, [BVerfGG] [Federal Constitutional Court Act] Art. 76, 93 et seq. (Ger).

50 Grundgesetz, [GG] [Constitution] Art. 100(1) (Ger).

51 Bundesverfassungsgerichtsgesetz, [BVerfGG] [Federal Constitutional Court Act] Art. 80 et seq. (Ger).

52 Grundgesetz, [GG] [Constitution] Art. 1 to Art. 19 (Ger).

53 Grundgesetz, [GG] [Constitution] Art. 20 (4), Arts. 33, 38, 101, 103, and 104 (Ger). 
These German Federal Constitutional Court procedures are set forth in the Basic Law and the Federal Constitutional Court Act in detail. The procedures for the Japanese counterpart are not found Japanese Constitution.

\section{Drafting history and the Court Act}

The officers at GHQ from the U.S. were engaged in the drafting process of the Japanese Constitution. The phrase "case and controversy" was not found in the GHQ draft of February 13, 1946. Three GHQ members and U.S. lawyers, Milo Rowell, Alfred Hussey, Jr., and Margaret Stone, worked on the judiciary chapter. The records show that there was not strong pressure for a special tribunal to preside over the constitutional law court at that time. The primary concerns were the people's sovereignty, the Emperor as a symbol, and demilitarization.

After accepting the Potsdam Declaration, for example, the government established a committee for judicial reform on November 9, 1945. It reviewed the democratization of the judiciary and found that the prosecutor's office should move from the judiciary to the Ministry of Justice because the investigation infringed on the rights of the people. ${ }^{54}$

Section 228 (c) (3) of the SWNCC (State-War-Navy Coordinating Committee) provided that the Emperor and the Supreme Commander should ensure " $[\mathrm{t}]$ hat any other bodies shall possess only temporary veto power [Emphasis by author] over legislative measures, including constitutional amendments approved by the representative legislative body, and that such body shall have sole authority over financial measures."

The GHQ draft of February 13, 1946 reflected the discussions of the lawyers in the Government Section (GS), especially Rowell, who participated in a small drafting committee for the chapter on the judiciary.

The term "temporary veto power" in SWNCC-228 meant that the legislative body was to be strong. In discussing the GS, some argued that more than temporary veto power in the Supreme Court should be rejected.

The records states "Colonial Kades felt that SWNCC-228 limited us to granting only a temporary power of veto to the Supreme Court. Commander Hussey stated that [this 
limitation applied only to the Supreme Court's legislative veto, and that] we are warranted in giving the Supreme Court absolute power of review over questions of constitutional interpretation." 56

This discussion concluded that giving veto power to the Supreme Court for its review of legislation without a concrete dispute was against SWNCC-283 and that the Supreme Court was able to resolve constitutional interpretation issues in concrete disputes over the authority of the legislative body. ${ }^{57}$

Other records indicated that the oligarchy of the judiciary might distort the legislative body with judicial review, but this was not a concern because the power of the legislature was strengthened in this draft. Rowell later noted that judicial review and the experience of the U.S. with the New Deal in the U.S. Supreme Court might be shocking to the Japanese people, combined with the principle that the court would be the supreme gatekeeper of the constitution with one legislative body as the highest power. ${ }^{58}$

In "the Outline of the Constitution Draft", the non-governmental party drafts contained chapters on the judiciary. For example, the Liberal Party, the Communist Party (Kyosan Tou), the Japan Progressive Party (Shinpo Tou), and the Japanese Socialist Party (Nihon Shakai Tou) prepared constitutional drafts. Some of them stated that the Supreme Court should be the highest court and that it should manage all of inferior courts, and that the president of the Supreme Court should be publicly elected. This advanced draft did not mention disputes on laws. ${ }^{59}$

The "Outline of the Constitution Draft" was prepared by the Constitution Investigation Association and had three versions. Two of these did not stipulate language regarding disputes on laws. ${ }^{60}$ The third draft provided for a special tribunal to preside over disputes regarding the power between governmental bodies. The head of this special tribunal was the president of the judiciary and judges were selected from among Supreme Court Judges,

56 Id. at 123.

57 KENZO TAKAYANAGI, ICHIRO OHTOMO, and HIDEO TANAKA, NIHONKOKU KENPO SEITEI NO KATEI [The Making of the Constitution of Japan, Vol. II Comments] 230-243 (Yuhikaku 1995).

$58 \quad I d$. at 243.

59 KENPO SEIRITSUSI VOL. I, supra note 3 at 733-884.

60 Id. at 826 and 829. It was not clear who submitted the "Outline of the Constitution Draft" to the GHQ. 
legislative members, and lawyers.

The discussion regarding the phrase "case and controversy" or disputes on laws ${ }^{61}$ identical and was left for the next generation of Japanese constitutional law scholars to determine.

\section{A case for the National Police Reserve and the possibility of a Constitutional Court}

The National Police Reserve, the predecessor of the Self-Defense Force, was established just before Japan gained its independence in 1952 by concluding the San Francisco Peace Treaty. Mosaburo Suzuki, head of the Japanese Socialist Party, brought suit directly to the Supreme Court. In 1952, the Supreme Court ${ }^{62}$ dismissed his suit on the grounds that he lacked standing because he was only the head of a political party and no injury was caused by the establishment of the National Police Reserve; the Supreme Court announced its position as a U.S.-type judiciary. Unlike in the U.S. Constitution, judicial review was stipulated in Article $81^{63}$ of the Japanese Constitution but the terms of a case and controversy were not included. ${ }^{64}$ Disputes on laws are only addressed in the Japanese Court Act. $^{65}$

Thus, if we take this decision seriously, it would be unconstitutional to establish a constitutional tribunal that has abstract judicial review and it would overturn this important constitutional precedent.

The Court Act was revised in 1947 with the current Japanese Constitution. Around the

61 In Japan, there is a controversy that if a dispute regarding a law is identical with a case and controversy as set forth in Article III of the U.S. Constitution.

Tsuji, supra note 24 at 75,77.

62 Saiko Saibansho [Sup. Ct.] October 8, 1952, Showa 27 (ma) no. 23, 6(9) Saiko Saibansho Minji Hanreishu [Minshu] 783.

63 Nihonkoku Kenpo [Kenpo][Constitution], Art. 81. The Supreme Court is the court of last resort with the power to determine the constitutionality of any law, order, regulation or official act.

64 SOUICHI SASAKI, KAITEI NIHONKOKUKENPO [Japanese Constitution, Revised] 342-33 and 356-357 (Yuhikaku 1952). Prof. Sasaki explained how the judiciary would operate in a concrete case, that the judiciary should not be willing to solve constitutional interpretative issues without a case, and that judicial review operates under statute. Sasaki noted that the Supreme Court should exercise judicial review.

65 Saibansho Hou [Japanese Court Act], Law No. 48 of 2013, Art. 3(1) (Japan). Courts shall, except as specifically provided for in the Constitution of Japan, decide all legal disputes, and have such other powers as are specifically provided for by law. 
time of the establishment of the National Police Reserve, parliament discussed a proposal to amend the Court Act to delete the phrase "disputes on laws" and added a new procedure for abstract judicial review. This revision to the Court Act was submitted in 1957 and proposed a reorganization of the Supreme Court. In the beginning, the heavy burden of the Supreme Court was recognized.

Around 1955, several constitutional scholars proposed reforming the Supreme Court and Article $81 .^{66}$ Prof. Isao Sato argued that we should modify Article 81 of the Japanese Constitution to include special procedures for a special constitutional tribunal to preside over constitutional interpretation cases if the Supreme Court was the only court that could review constitutional interpretation cases. ${ }^{67}$ Prof. Jorji Tagami noted that only the Diet, the executive branch, and the judiciary could bring constitutional interpretation litigation. ${ }^{68}$

Prof. Kunitoshi Ohnishi suggested pre-review and Prof. Kenzo Takayanagi argued for advisory opinions from the Supreme Court and that it should be possible to establish a special branch in the Supreme Court like the German Constitutional Tribunal without amending the Japanese Constitution. Prof. Toshiyoshi Miyazawa's opinion was that the court's advisory opinions should be limited. ${ }^{69}$

Prof. Anzo Suzuki agreed with the heavy burden of the Supreme Court, argued for a special branch for general appeals in the high court, and also argued that the Supreme Court should be the only court to render constitutional interpretation decisions. ${ }^{70}$

The proposal to establish a special branch within the Supreme Court to exclusively review constitutional cases is similar to the certiorari system in the U.S. The heavy burden of routine cases in the Supreme Court resulted in the loss of to focus on important constitutional interpretation cases. Some constitutional scholars argued that this proposal was too old arguments at that time to justify today. ${ }^{71}$

66 NONAKA ET.AL. VOL. I, supra note 10 at $77-78$.

67 JISHU KENPO KISEI GIIN DOMEI, KENPO KAISEI NO MONDAITEN [The Problems with Amending the Constitution] 536-546, 556 (1955).

68 Id.

$69 \mathrm{Id}$.

70 Id.

71 HIDENORI TOMATSU, KENPO [Constitution] 463 (Kobundo 2015). Tomatsu believes that only in the early stage of Japanese Constitution it was possible to think that the Japanese judiciary had abstract review until the National Police Reserve Case was rendered.

MASATO ICHIKAWA, KENPO [Constitution] 350 (Shinseisha 2014). Ichikawa and Tomatsu 
In 2005, the LDP submitted its own constitutional draft ${ }^{72}$ requesting the establishment of a constitutional court. Another draft ${ }^{73}$ in 2012 submitted by the LDP did not include provisions for a constitutional court. For those who oppose the Abe Cabinet and think that an amendment to the constitution is needed, the establishment of a constitutional court might not sound like a good idea. Those people may fear that this new court may fall into the political majority's control and may need another strategy to further Abe's security and defense statutes.

One approach to Nagoya's high court decision ${ }^{74}$ might be available. In order for the Japanese government to send ground and maritime SDF forces to Iraq for rebuilding, the Diet enacted special statutes in 2003, which were valid for four years. The government extended them for an additional two years through 2009. The special laws ${ }^{75}$ regarding Iraqi humanitarian and reconstruction assistance were generalized in the 2015 Defense and Security Act with no expiration date.

Nagoya's high court followed the CLB public interpretation of Article 9 pertaining to the SDF and endorsed the existence of the right to live in peace as provided in the preamble of the Japanese Constitution. The court stated no infringe on the right to live in peace but it recognized the right with legal norms. The court found a difficult distinction between combat and non-combat regions.

The Nagoya high court endorses the right to live in peace and by denying a distinction between combat and non-combat regions, the court remanded the issue back to parliament for further deliberation. The Nagoya high court has the advantage that the judiciary maintains its authority and power of judicial review and encourages the legislature to review

emphasize the National Police Reserve case. See also, Tsuji, supra note 24 at 79-81.

72 Kunihiko Morohashi, Main Constitutional Amendments Drafts and Proposals, 537 Research and Information (Issue Brief) 1 (2006). Available at http://www.ndl.go.jp/jp/diet/publication/issue/0537. pdf (last visited on February 18, 2016).

73 Constitutional draft submitted by the LDP. Available at https://www.jimin.jp/policy/policy_topics/ pdf/seisaku-109.pdf (last visited on February 18, 2016).

See also, GLENN HOOK \& GAVEAN MACCORMACK, JAPAN'S CONTESTED CONSTITUTION 34 (Routledge 2001).

Peace in Theory and Practice, supra note 3 at 820.

74 Nagoya Koto Saibansho [Nagoya High Ct.], April 17, 2008. Heisei 18 (ne) no. 499. Tsuji, supra note 24 at $71-73$.

75 Law Concerning Special Measures on Humanitarian and Reconstruction Assistance in Iraq. Law No. 37 of 2003 (Japan) [expired]. 
statutes regarding Article 9.

\section{Reconstruction of National Defense During the Abe Administration}

\section{Several patterns of attack}

In 2007, the first Abe Cabinet called a committee meeting for the reconstruction of national security (Anzen Hoshou no Houteki Kiban no Saikouchiku ni kansuru Kondankai). From September 2007 to December 2012, it was not convened under the Democratic Party ruling. The second Abe Administration came to power through an election in the House of Representatives in December 2012 and the committee resumed its discussion of collective defense power.

The committee concluded several cases regarding joint defense activity, which at the time was only permissible under Article 5 of the security treaty between Japan and the United States. $^{76}$

First, preemptive attacks were unacceptable even when one country was prepared to launch a missile targeting Japan. Only an exclusively defensive security policy (Senshu Bouei) was constitutional. The SDF was organized only for self-defense with no capability to attack foreign governments outside of Japanese territory. The SDF has the capacity to intercept missiles flying into Japanese territory.

Second, intercepting a missile that targets the U.S. over Japanese territory would be included in collective defense power, ${ }^{77}$ even if the missile does not target Japan. If it targets the U.S., the Aegis Combat System would be activated in the U.S.

Third, intercepting a missile targeting Japan is permissible as a defensive action. It is, however, difficult to intercept missiles. If the missile landed, then the defense and security treaty between Japan and the U.S. would be triggered.

Fourth, attacking U.S. forces stationed in Japan activates the treaty between the U.S. and Japan. Pre-2014, the Japanese government explained that to defense for Japanese people near the U.S forces base is included in its individual defensive power and the U.S.

76 Nihonkoku to Amerika Gasshukoku to no aidano anzen hoshou jouyaku [Treaty of Mutual

Cooperation and Security Between Japan and the United States], Japan-U.S., January 19, 1960, Treaty No. 6.

77 SAKATA, supra note 23 at 70. 
government stated that activating the treaty based on an attack on its forces is part of the collective defense power.

Fifth, if a fighter aircraft flies into Japanese airspace, Japanese SDF air forces will scramble for take off. Typically, fighter aircraft fly in an air defense identification zone (ADIZ), in which case, the SDF will scramble for take off.

Sixth, supporting U.S. marine ships was included in the collective defense power. Three conditions must be met to exercise self-defense power: an immediate and imminent threat must occur; no alternative measure must exist; and the required minimum ability to use its self-defense power must exist. In order to protect the Japanese territory, the pre-2014 interpretation found that the SDF may assist U.S. marine ships as an individual defense power. $^{78}$

Seventh, detecting and disposing of underwater mines placed by other countries was included in collective defense power. If underwater mines targeted Japan, the SDF could exercise individual defense power, which was an impractical theory because underwater mines are usually placed for any ship that navigates the country's water.

Eighth, if a Japanese citizen is under attack in foreign territory, Japan is prohibited from sending the SDF outside Japanese territory.

In May 2014, this private committee submitted several proposals to the Abe Administration advising that amendments to the existing defense statutes were needed to clarify the scope of collective power. ${ }^{79}$

In February 2016, the Ministry of Foreign Affairs explained, "[t]he security environment around Japan has become increasingly severe as represented by nuclear and missile development in North Korea. Transnational threats grounded on technological progress including international terrorism and cyber attacks are also increasing." 80

New phases of war, including cyber war and counter terrorism by police, were not much discussed in detail during the meetings of this private committee. Those against the

\section{Id at 62.}

79 See also, Yuichiro Tsuji, Constitutional Amendment, 37 Nanzan Review of American Studies 51 (2015) [hereinafter Constitutional Amendment].

80 Japan's Security/Peace and Stability of the International Community. Ministry of Foreign Affairs, February 10, 2016. Available at http://www.mofa.go.jp/policy/security/ (last visited on February 18, 2016). 
2014 Abe Cabinet decision believe that these new phases would not fall solely under individual defense power.

\section{The Constitution and the LDP in Japan}

The LDP was formed in 1955, three years after Japan signed the San Francisco Peace Treaty. ${ }^{81}$ The LDP was the ruling party and the largest opposition party was the Japanese Socialist Party. The LDP's goal was to establish its own constitution for the Japanese people and Abe attempted to achieve that goal.

Prof. Yoichi Higuchi explained the unique Japanese political phenomena of the LDP. The Japanese prime minister purposely didn't put constitutional reforms on the political agenda, even though he supported amending the constitution. Japanese people were both for and against constitutional amendments within LDP factions. ${ }^{82}$ Japanese constitutional law scholars should research intra-factional conflicts and questions whether changing party leaders reflects the will of voters.

After the 1993 collapse of the "1955 system" (55 Nen Taisei), Japanese people saw not only constitutional amendments but intra-factional competition within the LDP. There have been no major party changes; thus, Japanese people have only experienced the political games between the right and left wings of the LDP. It is not clear whether this unique political situation would influence a certain Japanese constitutional administrative power or interpretation of Article 9. Arikawa and Hasebe point out that the 2014 cabinet decision was made in haste and impaired the rule of law and Japan's legal stability as a sovereign nation. ${ }^{83}$

\section{Pre-article 9 Japan}

Although one of the private drafts by Japanese constitutional scholars recommended establishing a presidential system, the Japanese Constitution adopted the parliamentary system. The cabinet is subject to the confidence of the Diet. ${ }^{84}$ The prime minister is one of

81 Nippon Koku to no Heiwa Jouyaku [Treaty of Peace with Japan], April 28, 1952, Treaty No. 5.

82 YOUICHI HIGUCHI, KENPO KAISEI DOU KANGAERUKA [How to Consider Amendments to the Constitution Today] 57, 59 (Iwanamishoten 2013).

83 For more information on their arguments, see Constitutional Amendment, supra note 79 at 58-.

84 Nihonkoku Kenpo [Kenpo][Constitution], Art. 69. If the House of Representatives passes a non- 
the members of the Diet and the House of Representatives may pass a non-confidence resolution or reject a confidence resolution to force the cabinet to resign through the use of Article 69 of the Japanese Constitution.

Before analyzing Article 9, a few other constitutional issues will be discussed.

\section{Controlling executive power with the constitution}

The prime minister acts as the supreme commander of the SDF. Executive power belongs to the cabinet through Article $65^{85}$ of the Japanese Constitution. The Meiji Constitution was similar to the Prussian Constitution in that the Emperor ${ }^{86}$ had strong power and the Imperial Diet ${ }^{87}$ was merely a supporter of the Emperor.

The current Japanese Constitution follows the English cabinet and parliamentary system. The highest-ranking person in the cabinet is the prime minister, who has the authority to appoint and remove ministers. ${ }^{88}$

The cabinet's mission is to implement statutes, draft general and basic policies, and direct and supervise the administrative branches. The cabinet is divided into three roles as explained by constitutional scholars in Japan. ${ }^{89}$

The highest level is the administration, which makes, directs, and supervises policy via Article $65 .{ }^{90}$ The second level derives from management, which maintains and develops the organization to efficiently implement administrative purposes. The third level is the implementation of statutes and regulations on the front line, led by inferior officials. This understanding is one of several interpretations of Articles 65 and $72^{91}$ of the Japanese Constitution.

confidence resolution, or rejects a confidence resolution, the Cabinet shall resign en masse, unless the House of Representatives is dissolved within ten (10) days.

85 See id. Art. 65. Executive power shall be vested in the Cabinet.

86 Dainihon Teikoku Kenpo [Kenpo] [Meiji Constitution, Constitution of the Empire of Japan], Art. 1.

87 See id. Arts. 5 and 7.

Yoichi Higuchi, The Constitution and the Emperor System, JAPANESE CONSTITUTIONAL LAW, supra note 42 at 58 -.

88 Nihonkoku Kenpo [Kenpo][Constitution], Arts. 66-68.

89 MASANARI SAKAMOTO, KENPO 1 CLASSIKUSU [CONSTITUTION I CLASSIC] 195 (Yuchindo 2000).

90 Id. See also, SHIGENORI MATSUI, KENPO [Constitution of Japan] 213-217 (Yuhikaku 2007).

91 Nihonkoku Kenpo [Kenpo][Constitution], Art. 72. 
Generally, Japanese constitutional studies ${ }^{92}$ focus on cabinet leadership, because the Meiji government lost control ${ }^{93}$ as a result of military interference during events such as the 226 coup d'État (the February 26 incident) in 1936. The prime minister was simply one of many ministers and had no power to remove the ministers who were against the cabinet under the Meiji Constitution; ${ }^{94}$ thus, they needed to resign as a whole, and it is worth noting that the military was against the cabinet.

Details regarding cabinet meetings are not stipulated in the Japanese Constitution. ${ }^{95}$ Decision-making in the cabinet is autonomous and is beyond judicial review but is accountable to the legislature. ${ }^{96}$ The cabinet and legislature work together to shape mid- and long-term goals regarding basic and general policies. The NSC must provide free access to information to the general public.

In the activities set forth in the 2015 National Defense Acts, the extent of control through legislation is different. These statutes stipulate pre- or post-approval of the Diet.

The control of executive power by the legislature is stipulated in the Japanese Constitution. ${ }^{97}$ Article 61 of the Japanese Constitution stipulates that the Diet must approve a treaty that is concluded by the cabinet. ${ }^{98}$ The legislature approves treaties with other nations that are concluded by the cabinet. This procedure is clearly written in Article 73(3) of the Japanese Constitution. ${ }^{99}$ Any treaty executed without the consent of the Diet will have no effect. The Japanese Constitution cannot be altered by a treaty because the power to

92 KOJI SATO, supra note 12 at 480.

TOSHIHIKO NONAKA, MUTSUO NAKAMURA, KAZUYUKI TAKAHASHI, and KATSUTOSHI TAKAMI, KENPO II [Constitution II] 166 (Yuhikaku 2012) [hereinafter NONAKA ET. AL VOL. II ].

93 Dainihon Teikoku Kenpo [Meiji Constitution, Constitution of the Empire of Japan], Arts. 11 and 55.

94 See id. Art. 55.

95 Naikaku Hou [The Cabinet Act], Law No. 33 of 2015, Arts. 4 and 6.

96 See id. Art. 1. Nihonkoku Kenpo [Kenpo][Constitution], Art. 69.

97 Nihonkoku Kenpo [Kenpo][Constitution], Art. 60(2). Upon consideration of the budget, when the House of Councilors makes a decision different from that of the House of Representatives, and when no agreement can be reached even through a joint committee of both Houses, provided for by law, or in the case of failure by the House of Councilors to take final action within thirty (30) days, the period of recess excluded, after the receipt of the budget passed by the House of Representatives, the decision of the House of Representatives shall be the decision of the Diet.

98 See id. Art. 61. The second paragraph of the preceding article applies to the approval of the Diet as required for the conclusion of treaties.

99 See id. Art. 73(3). 
conclude and approve treaties is granted by the constitution. ${ }^{100}$ Detailed executive agreements under a treaty do not require the legislature's approval. Important, complicated matters might be included in the executive agreement and not in the treaty.

As in other parliamentary systems, the legislative and executive powers are required to work together. Their deliberations are typically in favor of the majority, but they must reflect the opinions of the minorities who are unable to convey their positions to the democratic branches. There was poor decision-making during the 2015 defense and security bill deliberations and those who were against the Abe government argued that the doctrine was passed in order to avoid judicial review in the name of autonomy in the House of the Diet. ${ }^{101}$

The judiciary is a passive branch. It avoids unnecessary political disputes and cannot review its autonomy from the political branches such as through cabinet meetings or committee deliberations. ${ }^{102}$ However, there may be space for the judiciary to review issues such as those involving the infringement of human rights. ${ }^{103}$

\section{Special tribunals independent of the judiciary}

Under the 2012 LDP constitutional draft, a military court was established in the National Defense Force. Article 60 of the Meiji Constitution ${ }^{104}$ accepted the military court, which was independent of the regular judiciary. A soldier may commit certain actions that are prohibited in the general criminal code. Thus, it is necessary to keep military order and determine legality in a special tribunal independent of the regular judiciary.

According to the current Japanese Constitution, the judiciary has special courts that have jurisdiction over certain cases in the hierarchy of the judiciary. ${ }^{105}$ There are special tribunals with jurisdiction over certain cases with the possibility of an appeal to a higher court in venues such as the Tokyo Intellectual Property Court or in family courts. Without amending Article $76(2)^{106}$ of the Japanese Constitution, it is easy to imagine the existence of

100 See id. Art. 98.

101 Tsuji, supra note 24 at 68-.

102 Id.

103 KOJI SATO, supra note 12 at 464.

104 Dainihon Teikoku Kenpo [Meiji Constitution, Constitution of the Empire of Japan], Art. 60.

105 Nihonkoku Kenpo [Kenpo][Constitution], Art. 76(2). No extraordinary tribunal shall be established, nor shall any organ or agency of the Executive be given final judicial power.

106 Yuichiro Tsuji, Why Does the Japanese Constitution Not Include the Creation of a Special 
special courts if an appeal to general court is available. In the 226 coup d'État (February 26 incident) of 1936, military officers advocated for a revolution and led inferior soldiers in an attack on the government. They assassinated the prime minister and several other ministers. The government ordered this insurgent troop to return to the original force in two days. The officers were sentenced to death without a fair trial in a special military tribunal not open to public, which was established by an edict of the Emperor and not by statute.

\section{The 2015 national defense and security statutes}

In 2014, the Abe Administration created three new conditions to make defense power permissible under Article 9. First, an attack on Japan must occur, a nation in a close relationship with Japan must be attacked, the existence of the Japanese nation must be endangered, or it must be clear that life, liberty, and the right to the pursuit of happiness is threatened. Second, there must be no alternative measures to prevent the attack, preserve the nation, and protect the people. Third, its exercise must meet the necessary minimum requirements.

The Diet amended the Self-Defense Force Act. ${ }^{107}$ Previously, Article 3 of the SDF Act limited SDF defense activity against direct or indirect invasion. This meant that the SDF could exercise only defensive security activities known as Senshu Bouei. The phrase "direct or indirect" was subsequently deleted. Previously, Article 76 of the SDF Act provided for defense activities. A new condition in Paragraph 2 of Article $76^{108}$ was added: "a nation in a close relationship with Japan is attacked, the existence of the Japanese nation is endangered, or it is clear that life, liberty, and the right to the pursuit of happiness is threatened." Article 76 authorized the sending the force to maintain security and peace. Article $88^{109}$ provides for the use of force for defense.

Buryoku Kogeki Jitai Hou ${ }^{110}$ or the Act Concerning Measures for the Protection of the People in Armed Attack Situations, Etc. was passed in the Diet. This act provides for three

Tribunal?, 23(1) Surugadai Journal of Law and Politics 170 (2009).

107 Jiei Tai Hou [The Self-Defense Force Act], Act No. 76 as of 2015, Art. 3.

108 See id. Art. 76.

109 See id. Art. 88.

110 Buryoku Kougeki Jitai tou ni okeru Wagakuni no Heiwa to Dokuritsu narabini Kuni oyobi Kokumin no Anezenn no Kakuho ni Kansuru Houritsu (Buyroku Kogeki Jitai hou) [Act Concerning Measures for the Protection of the People in Armed Attack Situations, Etc.], Act No. 76 as of 2015. 
types of situations that could occur when Japan is under attack. The first situation is when an armed attack happens or there is clear and imminent danger of armed attack. The second is a predictable armed attack that does not reach the level of an armed attack but an armed attack is imminent. The third is an armed attack that includes the first and second situations. ${ }^{111}$ The purpose of this act is to ensure peace and independence for Japan and the Japanese people and to set forth the responsibilities and procedures for central and local governments. $^{112}$

The definition for Buryoku Kogeki Jitai should not be overbroad. The current definition is too difficult to understand. This Act added the new notion of Sonritsu Kiki Jitai. New wording for Sonritsu Kiki Jitai was created but it is difficult to translate into English and an official translation was not available as of February 2016. It likely means an armed attack against a foreign country resulting in a threat to Japan's survival. This language was added to Article 76 of the Self-Defense Force Act as well. ${ }^{113}$

The opposing political party criticized this complicated definition. The Abe Cabinet explained that the government reviewed the will of potential attacking nations, their capacity, their geographical locations, and their probability to cause war. In June, 2015, the Abe cabinet responded to the criticism that some the attack on the U.S. led to problems in Japan. $^{114}$

The goals of the Abe Cabinet are to permit the SDF to dispose of underwater mines in the Strait of Hormuz, ${ }^{115}$ to intercept missiles targeting the U.S., and to search and inspect suspected ships. The revised Article 76 of the Self-Defense Force Act did not provide conditions for taking these specific actions. ${ }^{116}$

\section{See id. Art. 2.}

112 See id. Art. 1.

113 Jiei Tai Hou [The Self-Defense Force Act], Act No. 76 as of 2015, Art. 76.

114 Shudan teki Jieiken Meihaku na Kiki de kousi kanou [Collective defense power is exercised by clear danger against the U.S. ship]. The Mainichi Shimbun, (July 11, 2015).

For a summary of the opinion of the Ministry of Defense (August 25, 2015), see http://www.mod. go.jp/j/press/kisha/2015/08/25.html (last visited on February 18, 2016).

115 NARAHIKO TOYOSHITA and SHOICHI KOSEKI, SHUDANTEKI JIEIKEN TO ANZEN HOSHUO [Collective Defense Power and Security] iv, v, and 26 (Iwanamishinsho 2014). Prof. Toyoshita feels that the limitations explained by Abe are nonsense because there is no public sea at that location and the Japanese SDF must accept the nation's (Iran or Iraq) consent to enter.

116 Jiei Tai Hou [The Self-Defense Force Act], Act No. 76 as of 2015, Art. 76. 
The Abe Cabinet's justification for the use of force may include the prevention of an economic crisis such as an insufficient supply of everyday commodities and electricity, which are vital to the survival of the Japanese people. It is not clear how the government will address general economic crises. As the Abe Cabinet notes, the Strait of Hormuz is very important for Japan in that the country imports approximately eighty percent of its oil from suppliers who move through that area. The opposing party responded that closing the strait would create an economic crisis, not Sonritsu Kiki Jitai, which was added to the Buryoku Kogeki Jitai Hou.

According to the government's explanation, this notion may entail the first requirement of the three new conditions to make defense permissible under Article 9. An attack on Japan must occur, a nation in a close relationship with Japan must be attacked, the existence of the Japanese nation must be endangered, or it must be clear that life, liberty, and the right to the pursuit of happiness is threatened.

Sonritsu Kiki Jitai is a case wherein collective defense forces operate when a nation that is close to Japan is attacked. ${ }^{117}$

Shuhen Jitai Hou ${ }^{118}$ or the Act on Measures to Ensure the Peace and Security of Japan in Perilous Situations in Areas Surrounding Japan was revised to Juyo Eikyo Jitai Hou ${ }^{119}$ or the Important Influencing Situations Act. The Japanese government has not yet provided an official English version of this act.

The government is responsible for clarifying this notion. It may be broader than Sonritsu Kiki Jitai on three points. First, the definition of Sonritsu Kiki Jitai includes a situation wherein Japanese peace and safety are in danger and it does not require an attack against Japan. Juyo Eikyo Jitai includes Sonritsu Kiki Jitai. Second, Sonritsu Kiki Jitai does

117 The Ministry of Foreign Affairs uses the phrase "Ittaika with use of force." There might be criticism as whether this is an appropriate notion under international law. "This is intended to keep Japan from being legally evaluated as carrying out the 'use of force' on its own, which is not permitted under the Constitution because its support activities would form an 'integral part' of the use of force ("ittaika with the use of force") by other countries." Available at http://www.mofa.go.jp/fp/ nsp/page23e_000273.html (last visited on February 18, 2016).

118 Shuhen Jitai ni saishite Wagakuni no Heiwa oyobi Anzen wo Kakuho surutameno Sochi ni kansuru Houritsu (Shuhen Jitai Hou) [Act on Measures to Ensure the Peace and Security of Japan in Perilous Situations in Areas Surrounding Japan], Act No. 60 of 1999.

119 Juyo Eikyo Jitai ni saishite Wagakuni no Heiwa oyobi Anzen wo Kakuho surutameno Sochi ni kansuru Houritsu (Juyo Eikyo Jitai Hou) [Important Influencing Situations Act], Act No. 76 of 2015. 
not contain the geographic limitations found in Shuhen Jitai such as the perilous situation surrounding Japan provision in the previous act, which predicted disputes on the Korean Peninsula; sending the SDF to the Middle East and Indian Ocean was not permitted due to geographic limitations. This new act enables the government to send the SDF to the Strait of Hormuz and the South China Sea with no geographic limitations. Third, the SDF can exercise the use of force in Sonritsu Kiki Jitai, not in Juyo Eikyo Jitai. Juyo Eikyo Jitai Hou, which was revised to Shuhen Jitai Hou and enables the government to send in the SDF for logistical support. In order to address Juyo Eikyo Jitai, the SDF may work with U.S. forces or foreign forces contributing to U.N. purposes or those of other, similar organizations. The SDF may carry fuel, conduct aerial refueling, transport goods to the U.S. Army, clean up interferences in the South China Sea, and maintain sea lanes.

The opposition party complained that logistical support raises the risk of war in which the Japanese SDF may be involved. A detailed explanation was available on the website of Masahisa Sato, a member of the LDP and the House of Councilors. ${ }^{120}$ Sato explains that if closing the Strait of Hormuz in the Middle East constitutes Sonritsu Kiki Jitai, it does not overlap with Juyo Eikyo Jitai, although he posted his own interpretation on his website. He was temporary commissioner for peace and defense statutes in 2015. It might show difficulty to understand these definitions.

The government raised the complicated notion of Buryoku Kosi no Ittaika, an activity integrated with the use of force. When Japan is not attacked directly, Article 9 prohibits the SDF from taking actions that are integrated with the use of the force. There are several requirements: the SDF cannot work in places where combat is occurring, the foreign government must consent to Japanese SDF work, and the SDF must stop performing in cases where activities cannot be performed safely. The SDF can provide logistical support until combat begins. The SDF may search, rescue, and inspect ships under the Inspection Activity of Ships Act. ${ }^{121}$ Other necessary measures may be taken to address the issue of Juyo

120 Masahisa Sato, Juyo Eikyo Jitai, Sonritsu Kiki Jitai, Buryoku Eikyou Jitai no Kankei [Relationship and distinction among Juyo Eikyo Jitai and Sonritsu Kiki Jitai and Buryoku Eikyou Jitai].

Available at http://ameblo.jp/satomasahisa/entry-12035744848.html (last visited on February 18, 2016).

121 Juyo Eikyo Jitai ni saishite Jissisuru Senpaku Kensa Katsudo ni kansuru Houritsu [Inspection Activity of Ships Act], Act No. 76 of 2015. 
Eikyo Jitai.

The director of the SDF may temporarily suspend its mission when combat occurs in the region or nearby or when combat is expected to occur. The Ministry of Defense designates the region of SDF activity and suspends its mission or changes the designated region when all or part of a locations makes it difficult to perform its mission.

Kokusai Heiwa Kyoryoku Hou ${ }^{122}$ or the Act on Cooperation with United Nations Peacekeeping Operations and Other Operations, was promulgated in 2015. In Japan, it is called the new PKO (Peacekeeping Operations) Act. The SDF can work on International Peace Cooperation Assignments ${ }^{123}$ and peacekeeping operations. The SDF may perform humanitarian and reconstruction assistance activities and peacekeeping activities not under the direction of the U.N.

Five principles have been set forth to ensure that participation in peacekeeping operations is in accordance with Article 9 of the Constitution:

(1) Agreement on a cease-fire shall have been reached among the parties to armed conflicts. (2) Consent for the undertaking of UN Peacekeeping Operations and Japan's participation in such operations shall have been obtained from the host countries as well as the parties to armed conflicts.

(3) The operations shall strictly maintain impartiality, not favoring any of the parties to armed conflicts. (4) Should any of the requirements in the above-mentioned principles cease to be satisfied, the Government of Japan may withdraw the Self-Defense Force (SDF) contingent. (5) The use of weapons shall be limited to the minimum necessary to protect the lives of personnel, etc. ${ }^{124}$

There are other conditions that the government must satisfy prior to sending the SDF

122 Kokusai Rengo Heiwa Iji Katsudou tou ni taisuru Kyouryokuni kansuru Houritsu (Kokusai Heiwa Kyoryoku Hou) [Act on Cooperation with United Nations Peacekeeping Operations and Other Operations], Act No. 76 of 2015.

123 The "International Peace Cooperation Assignments" that Japan conducts refer to the following tasks implemented for United Nations Peacekeeping Operations, tasks provided below in (10) to (17) for International Humanitarian Relief Operations, and in (7) and (17) for International Election Observation Operations (Article 3, item 3).

(7) Observation or management of the fair execution of elections for a representative assembly, referendums or any other similar elections or voting.

(17) Other tasks similar to those listed in (1) to (16) above as specified by Cabinet Order.

124 The Ministry of Foreign Affairs, Japan's Contribution to UN Peacekeeping Operations (PKO), Outline of Japan's International Peace Cooperation. Available at http://www.mofa.go.jp/fp/ipc/ page22e_000683.html (last visited on 26 in February, 2016). 
overseas. The first condition is upon a resolution of a general meeting of the U.N., the U.N. Economic and Social Council, or the U.N. Security Council.

Second, the SDF may be dispatched upon request from the U.N., an organization or special department established by a general meeting of the U.N., the Office of the U.N. High Commissioner for Refugees, or other groups established by ministerial order. Regional experience with a special organization is necessary for this activity under Article 52 of the U.N. Charter or with an organization established by multiple governmental treaties as provided by the European Union or other ordinance.

Third, the SDF may be dispatched upon request from the government where PKO activities are being performed only if it is supported by a principal organization as set forth in Article 7 of the U.N. Charter.

The distinction between combat and non-combat regions has been maintained. The Japanese government may send the SDF to non-combat regions only. SDF activity integrated into the use of force is prohibited.

This new act expands the scope of SDF missions. Not only is ceasefire monitoring and supporting victims permitted but rushing to the rescue Japanese people outside Japanese territory (Kaketsuke Keigo) was also added.

The condition to use weapons was also revised. In the case of the SDF aiding Japanese people outside of its territory, weapon use is permitted only when performing Kaketsuke Keigo rescue missions. A safe program exists for the temporary suspension of a mission to aid any SDF member in danger.

Ceasefire monitoring and ensuring safety require prior Diet approval. Only when the House of Representatives is closed or dissolved, post approval is possible.

\section{Approval of the Diet}

The most important changes were that the exclusively defensive security policy known as Senshu Bouei and the geographic limits were dissolved. SDF activity is controlled by parliament. The degree of control varies according to defense and peace statutes enacted in 2015.

First, the strongest level of control is pre-approval of the Diet in any case. This was 
outlined in the Kokusai Heiwa Sien $\mathrm{Hou}^{125}$ or the International Peace Supporting Act.

There is no exception for pre-approval. ${ }^{126}$ The cabinet is obligated to report to the Diet for a basic plan and policy. ${ }^{127}$ The Houses of the Diet must approve that plan and policy within seven (7) days. Post-approval is permitted only if the Houses of the Diet is closed or the House of the Representatives is dissolved. The cabinet must report to the Diet on any change to the basic plan. ${ }^{128}$

Prior to this act, the Diet enacted legislation containing a specified duration for when the government sent the SDF overseas. In October 2001, after the 9/11 terrorist attacks, the Japanese government passed the Counter Terrorism at Sea Act; it specified a duration of two (2) years. ${ }^{129}$ Under Kokusai Heiwa Sien Hou, the SDF would monitor ceasefires and support disaster victims. After two years, additional approval of the Diet was required. ${ }^{130}$

The Buryoku Kogeki Jitai Hou or the Act Concerning Measures for the Protection of the People in Armed Attack Situations, Etc. requires prior approval of the Diet soon after a cabinet decision is made. ${ }^{131}$

Juyo Eikyo Jitai Hou revised Shuhen Jitai Hou, requiring prior approval of the Diet. In an emergency, post-approval is required. ${ }^{132}$ Logistical support by the SDF and search and rescue activities must be approved by the Diet. ${ }^{133}$ The cabinet shall report to the Diet of any

125 Kokusai Heiwa Kyodo Taisho Jitai ni saishite Wagakuni ga Jissisuru Shogaikokuno Guntai tou ni taisuru Kyoryoku Sien Katsudo tou ni kansuru Houritsu (Kokusai Heiwa Sien Hou) [International Peace Supporting Act], Act No. 77 of 2015.

126 See id. Arts. 5 and 6.

127 See id. Art. 4.

128 See id. Art. 5(1).

129 Tero Taisaku Kaijou Oshi Katsudo ni taisuru Hokyu Sien Katsudo no Jisshi ni Kansuru Tokubetsu Sochi Hou, (Counter Terrorism at Sea Act) [Act on Special Measures for Implementation Supply and Support for Activities Regarding Counter Terrorism at Sea], No. 113 of 2001.

130 Kokusai Heiwa Kyodo Taisho Jitai ni saishite Wagakuni ga Jissisuru Shogaikokuno Guntai tou ni taisuru Kyoryoku Sien Katsudo tou ni kansuru Houritsu (Kokusai Heiwa Sien Hou) [International Peace Supporting Act], Act No. 77 of 2015, Art. 6(3).

131 Buryoku Kougeki Jitai tou ni okeru Wagakuni no Heiwa to Dokuritsu narabini Kuni oyobi Kokumin no Anezenn no Kakuho ni Kansuru Houritsu (Buyroku Kogeki Jitai hou) [Act Concerning Measures for the Protection of the People in Armed Attack Situations, Etc.], Act No. 76 as of 2015, Art. 9(4)(7)(10)(14)

132 Juyo Eikyo Jitai ni saishite Wagakuni no Heiwa oyobi Anzen wo Kakuho surutameno Sochi ni kansuru Houritsu (Juyo Eikyo Jitai Hou) [Important Influencing Situations Act], Act No. 76 of 2015, Art. 5.

133 See id. Art. 6. 
changes and responses to the basic plan.

The Kokusai Heiwa Kyoryoku Hou or the Act on Cooperation with the United Nations Peacekeeping Operations and Other Operations requires prior approval of the Diet in order for the SDF to support another country's army in ceasefire monitoring and ensuring safety. Post-approval is available only when the Diet is closed or the House of Representatives is dissolved. $^{134}$

Humanitarian rebuilding support does not need approval from the Diet. Determinations, changes in implementation, and duration change must be reported to the Diet. The original dispatching requirements are in force for two years and after the two-year period, reapproval by the Diet is necessary. The Diet makes every effort to approve a request within seven (7) days.

These statutes illustrate how a representative legislature controls the cabinet and the supreme commander of the SDF as well as the prime minister through the Japanese Constitution.

\section{Article 9 and Legal Stability}

\section{Responsibilities of the CLB}

Hasebe $^{135}$ points out that in 2014, Abe's Cabinet changed its interpretation of Article 9 pertaining to legal instability. Influenced by Joseph Raz and other scholars in the U.S., ${ }^{136}$ the 2014 cabinet decision dramatically changed these once fixed principles and rules. Hasebe might be true because since the promulgation of the current constitution, Japanese cabinets generally are in power only a few years. ${ }^{137}$ The prime minister is also the leader of the ruling

134 Kokusai Rengo Heiwa Iji Katsudou tou ni taisuru Kyouryokuni kansuru Houritsu (Kokusai Heiwa Kyoryoku Hou) [Act on Cooperation with United Nations Peacekeeping Operations and Other Operations], Act No. 76 of 2015, Art. 6(7)-(12).

135 YASUO HASEBE, Shudanteki Jieiken Kousi Younin ron no mondaiten [The Problems of Endorsing Collective Defense Power], 8 Jiyu to Seigi [Liberty and Justice] 65 (2014). YASUO HASEBE, KENSHO ANPO HOUAN [Review of the Security and Defense Bill] (Yuhikaku 2015).

136 YASUO HASEBE, HIKAKU FUNO NA KACHI NO MEIRO [Maze of Incommensurable Values, Constitutional Theory for Liberal Democracy] 152, 162, 165-(Tokyo University Press 2000). YASUO HASEBE, ANPO HOUSEI KARA KANGAERU RIKKENSHUGI MINSHUSHUGI [PEACE AND DEFENSE LAW FROM CONSTITUTIONALISM AND DEMOCRACY] (Yuhikaku 2016).

137 Shigeru Yoshida: 2616 days, Eisaku Sato: 2798 days, and Junishiro Koizumi: 1980 days. 
party under the parliamentary system. Intra-fractional political disputes have influence on the cabinet. The term of leaders in the political party is typically two or three years, ${ }^{138}$ as set forth by the party code. Thus, the position of the prime minister is subject to these intrafractional disputes.

Hasebe expressed a fear that important rules may face mid- and long-term changes due to short terms for prime ministers, causing people to distrust the rule of law and the management of the government. Hasebe believes in the CLB as the French Conseil d'État.

Hasebe's argument may be evidenced by the CLB's accountability after 2015. The CLB changed its public interpretation twice. ${ }^{139}$ One interpretation was Article 66(2), the civilian clause. The other was Article 9. The CLB is controlled by the cabinet and the Diet and the explanations by ministers using the CLB's public interpretation of Article 9 have been inconsistent. $^{140}$

Human dignity is a universal principle and people's viewpoints vary on how to maintain peace. The constitution works to create tools to keep universal values such as the dignity of humanity and the maintenance of stability among competing interests by using the rule of law.

Shigenori Matsui argues that "the existence of the SDF, despite the relatively clear provision prohibiting armed forces even for the purpose of self-defense, may underminethe rule of law and the basic assumption of constitutionalism" ${ }^{141}$

Shojiro Sakaguchi ${ }^{142}$ points out that the constitution works as a pre-commitment that binds the judgment of the future generation. As Hasebe and Sakaguchi argue, rule of law under the constitution must maintain mid- and long-term stability.

Stability is ultimately based on the people's decisions and plays into sovereignty. The people carve out their destiny, take responsibility, and accept their decisions. ${ }^{143}$ Democracy

138 Nihonkoku Kenpo [Kenpo][Constitution], Art. 45.The term of office for Members of the House of Representativesshall be four years. However, the term shall be terminated before the fullterm is up where the House of Representatives is dissolved.

139 SAKATA, supra note 23 at 162.

140 ASANO ET.AL, KENPO TOBENSHU [Answers from the Constitution] (Shinzansha 2003).

141 SHIGENORI MATSUI, THE CONSTITUTION OF JAPAN 255 (Hart publishing 2011).

142 SHOUJIRO SAKAGUCHI, RIKKENSHUGI TO MINSHUSHUGI [Constitutionalism and Democracy] (Nihon Hyoronsha 2001).

143 Constitutional Amendment, supra note 79 at $67-$. Tsuji, supra note 24 at 86-. 
uses various tools that supplement imperfect systems in Japan. The terms pertaining to defense and security are too complicated for the general public. One of the missions of constitutional law scholars in Japan is to bridge the gap between constitutional law texts and people's understanding. This supports the rule of law in Japan to maintain the universal values of the constitution.

\section{Ohishi and Fujita arguments}

In 2007, Prof. Makoto Ohishi, an advocate for the Abe Administration's interpretation of Article 9, analyzed the interpretation for the CLB. ${ }^{144}$ The mission of the CLB is to pursue logical consistency in the interpretation of statutes and the constitution. The CLB must be prudent in changing its interpretation and giving advice to the cabinet.

The content of collective defense power has not been clear under international law but is admitted through customary international law. Ohishi argues that an official explanation from the CLB has not effectively explained collective defense power. By citing statements made by members of the Diet, he argues that the CLB endorsed the existence of a collective defense power but denied the exercise thereof. He states that the CLB should show persuasive grounds for collective defense power. The silent interpretative approach may need answers from constitutional law scholars. Ohishi concludes that the Japanese Constitution does not prohibit collective defense power. He focused on the function of the CLB, which is to secure legal stability and predictability. He argues that a constitutional amendment is the best way to approve collective defense power.

Ex-Justice Tokiyasu Fujita states ${ }^{145}$ that the 2014 cabinet decision was an irrational political action and constitutional law scholars expressed strong criticism against the Abe Cabinet. He regrets that a majority of public law professors have not made consistent sophisticated analyses. Fujita analyzes that the pre-2014 official interpretation permitted only individual defense power not collective defense power. He put forth three principles in support of this approach.

144 Makoto Ohishi, Nihonkoku Kenpo to Shudan teki jieiken [The Japanese Constitution and Collective Defense Power] 1343 Jurist 37 (2007).

145 Tokiyasu Fujita, Oboegaki Shudan teki Jieiken no kousi Younin wo meguru Iken Ron [Note, Unconstitutional Opinion regarding Endorsement of Collective Defense Power] 92(2) Jichi Kenkyu 3 (2016). 
First, the interpretation of the constitution is important. If it the interpretation is wrong, we must correct it. We cannot prohibit modifications. The Supreme Court may vacate the decision and change the interpretation. Fujita thinks that valid reasoning is required if we need to change the interpretation of Article 9. Taking objection to Abe cabinet by his interpretation is against "Constitutionalism" is not strong enough and additional justification is needed why "legal stability" binds governmental interpretation so strictly. He suspects that an Article 9 interpretation will transform into a legal norm in the end.

Second, the CLB is an organization that assists the cabinet in interpretations. The CLB does not make the cabinet's interpretation binding. Fujita understood that Prime Minister Abe's statement "I am the final interpreter of the Constitution under the cabinet," has only temporary effect.

Third, the final interpreter of the constitution is the Supreme Court, not the CLB.

Fujita believes that constitutional law scholars should debut Abe cabinet interpretation of Article 9 in endorsing collective defense power if they want.

\section{The Inoue and Hasebe arguments}

Tatsuo Inoue, a legal philosophy specialist, argues that individual defense power and collective security under the U.N. are the best solutions for defense and security in Japan today. ${ }^{146} \mathrm{He}$ focuses on the history of GHQ interventions and the drafting of the Japanese Constitution. The U.S. has rule of law under its constitution and Japan can use the constitution to establish an equal relationship for peace and defense.

According to Inoue, an exclusively defensive security policy, known as Senshu Bouei, can be the subject of a constitutional amendment without using amendment procedures (Kaishaku Kaiken). The SDF and the treaty between Japan and the U.S. for defense and security purposes is unconstitutional.

Since the Japanese Constitution was promulgated, facts have accumulated. The 2014 cabinet decision expanded the SDF's activities. Inoue is against the 2014 decision and insists that Article 9 should be deleted unless the Japanese Constitution is amended under formal

146 TATSUO INOUE, RIBERARU NO KOTO HA KIRAI DEMO RIBERARIZUM HA KIRAI NI NARANAI DE KUDASAI [Even Though You Don't Like Liberals, Please Don't Like Liberalism] 4070 (Mainichi Shinbum Shuppan 2015). 
procedures as set forth in Article 96. ${ }^{147}$ By changing the public interpretation of the constitution without using formal amendment procedures (Kaishaku Kaiken), the core of constitutionalism is circumvented. Abe should have followed formal procedures for amending the constitution in order to endorse collective defense forces. It was certainly not impossible for Abe to receive a two-thirds majority in the Diet at that time.

By using formal procedures today, a discussion on amending the Japanese Constitution would be fruitful: how can we maintain a defense and security system in cooperation with the U.S.?

Hasebe and Ohishi would agree that the CLB must maintain the legal stability and predictability of its official interpretation of the constitution and statutes. They diverge in the attitude toward the cabinet decision of 2014.

Hasebe and Inoue, both former professors at Tokyo University, are in the same camp in arguing that the 2014 Abe Cabinet should have used formal procedures to amend the Japanese Constitution.

Inoue takes the opposite position. Inoue divides arguments against a constitutional amendment into two camps. One is a constitutional fundamentalist camp against a constitutional amendment. The other is the modified advocate camp that wishes to protect the constitution.

According to the Inoue analysis, fundamentalists against the constitutional amendment advocate for unarmed neutrality and absolute pacifism. Inoue thinks that this interpretation of Article 9 is more persuasive than that of the modified advocates because Article 9 clearly denies the use of force by the army. This is a poor explanation because the Japanese government endorses the existence of the SDF and the treaty for defense and security with the U.S. He doubts the non-violent resistance posture because it requires a serious commitment by the people.

In Inoue's viewpoint, the modified advocates for the protection of the constitution take a pre-2014 CLB position. They argue that by using Paragraph 2 of Article 9, invasive war is

147 Nihonkoku Kenpo [Kenpo][Constitution], Art. 96.Amendments to this Constitution shall be initiated by the Diet, through a concurring vote of two-thirds or more of all the members of each House and shall thereupon be submitted to the people for ratification, which shall require the affirmative vote of a majority of all votes cast thereon, at a special referendum or at such election as the Diet shall specify. 
prohibited and defensive war is permissible. Its interpretation is far beyond the text of the constitution. Declaring that the SDF and the treaty are unconstitutional is useful and they limit the scope of Article 9 in the political sphere.

Both Inoue and Hasebe may attempt to address the reality of an unconstitutional state of affairs in Japan in 2015. By deleting Article 9, Inoue argues that the government must maintain continuous discussions on defense and security under the normal legislative process. Without Article 9, neither can justify the use of force for self-defense. He argues for the reexamination of democratic deliberation.

Inoue believes that Japan must only act under the collective security of the U.N. He endorses the SDF and is against collective defense alliances with the U.S. He feels that Japan must be able to maintain a necessary minimum ability to defend itself.

Seeing the insufficient collective security system under the U.N., Inoue admits that there are few advantages to a treaty for defense and security with the U.S. Japan must commit to a collective defense system under the U.S. This would cover not only defense and security, but also education, culture, and preventative measures. A multifarious network for collective defense would be helpful for Japan.

\section{The Arguments of Mizushima and Yamamoto}

There are two professors with contrasting views from Waseda and Keio Universities. Mizushima, from Waseda University, has argued that individual and collective defense powers are distinguishable and that the pre-2014 government invoked only individual defense power which is not provided in the constitution. Its text barely permits individual defense power and the Abe Cabinet decision in 2014 destroyed it. ${ }^{148}$ He argues that there is no overlap between individual and collective defense power. ${ }^{149}$

A pre-2014 interpretation is important in the case of an immediate and imminent threat, for defense purposes. The constitution permits individual defense power as long as no alternative measure exists. It requires a minimum ability to use its self-defense power.

The 2014 cabinet decision states that without an attack on Japan, in the name of

148 ASAHO MIZUSHIMA, RAIBU KOUGI TETTEI BUNSEKI, SHUDANTEKI JIEIKEN [Live Lecture, Thorough Analysis, and Collective Defense Power] 44- (Iwanami Shoten 2015). Prof. Mizushima published other articles as well. 149 Id. at 71. 
defense, collective defense power may be exercised. The official Japanese interpretation before 2014 permits narrower individual defense power than the power permitted by international law. The SDF is an exception. An attack on our nation must come first, but this condition was destroyed in 2014. Abe induced collective defense power from the "inherent self-defense power" in the Sunagawa decision. Fujita, Mizushima, and Hasebe are in the same camp regarding the Sunagawa decision. Mizushima argues further that the Sunagawa decision references only inherent defense power. The CLB under the Abe administration induced both individual and collective defense power from this decision.

Mizushima points out that legislative facts in support of the defense and peace statutes do not exists. In this case, it is nonsense for Mizushima to consider peace and defense statutes as policy matters outside judicial review. This political accountability lacks the deliberation and explanation of 2014. By reviewing a precise translation of the U.N. Charter, the Abe Cabinet believed that collective defense power was a natural right. Mizushima sees it as clearly erroneous to use the word "inherent" ([le] droit naturel de légitime défense, individuelle ou collective). ${ }^{150}$ According to Mizhushima, it is ridiculous to find that the peace and defense statute passed in 2015 permits individual defense power but not collective defense power. ${ }^{151}$

Hajime Yamamoto, from Keio University, argues that it is possible to change the constitutional interpretation to endorse collective defense power without amending the constitution.

He denies the qualification by the Abe Cabinet to do it. The current peace and defense force does not necessarily require the cabinet to obtain prior approval from the Diet in the absence of an attack on Japan. Collective defense power should only be exercised under the U.N. Charter.

Three new conditions for the use of force were not limited but were subject to situation recognition and the value judgement of the cabinet from time to time. According to Yamamoto, the SDF was established by way of un-constitutionalism. The CLB changed the interpretation of Article 9 to permit individual defense power under which excising the

150 Id. at 62.

151 Id. at 75. See also, Fujita, supra note 145 at 29, n15. See also, Souta Kimura,

Anpo Hou an no doko ni Mondai ga arunoka [What is the problem of the peace and defense bills], KENSHO ANPO HOUAN, supra note 135 at 17-18. 
necessary minimum does not constitute "force." The SDF is in violation of Article 9 because of a distorted interpretation. The national consensus was in favor of changing the interpretation and changing the interpretation of Article 9 requires national consensus. The government needed to prove that it was time to change the interpretation of Article 9 without amending the constitution. It is nonsense for Yamamoto to ask the bureaucrat in the CLB to preserve one interpretation of the constitution and it is not appropriate for the cabinet to change the head of the CLB for according to his political preference.

Shuhen Jitai Hou ${ }^{152}$ or the Act on Measures to Ensure the Peace and Security of Japan in Perilous Situations in Areas Surrounding Japan, was revised to Juyo Eikyo Jitai Hou. ${ }^{153}$

There is no geographical limitation for SDF activities or distinction between combat and non-combat regions. Yamamoto suspects these revisions reflect and strengthen national defense under change of defense circumstances.

\section{Conclusion}

The Japanese Constitution is now facing amendment depending on elections in the House of Councilors in July in 2016, which may accelerate the Constitutional Council and a national referendum.

History shows that the Potsdam Declaration required the Japanese government to accept the conditions that the Japanese government surrender its armed forces and that a peaceful and responsible government be established by the will of the Japanese people. The MacArthur note illustrated that war as a sovereign right of the nation should be abolished. Japan renounced it "as an instrumentality for settling its disputes and even for preserving its own security. It relies upon higher ideals that are now stirring the world for its defense and its protection" provided in the preamble of Japanese Constitution. A Japanese Army, Navy, or Air Force will never be authorized and no rights of belligerency will ever be conferred

152 Shuhen Jitai ni saishite Wagakuni no Heiwa oyobi Anzen wo Kakuho surutameno Sochi ni kansuru Houritsu (Shuhen Jitai Hou) [Act on Measures to Ensure the Peace and Security of Japan in Perilous Situations in Areas Surrounding Japan], Act No. 60 of 1999.

153 Juyo Eikyo Jitai ni saishite Wagakuni no Heiwa oyobi Anzen wo Kakuho surutameno Sochi ni kansuru Houritsu (Juyo Eikyo Jitai Hou) [Important Influencing Situations Act], Act No. 76 of 2015. 
upon a Japanese force. ${ }^{154}$

The important modification in the second paragraph of Article 9 was made as a result of discussions in the Imperial Diet. Chairman Hitoshi Ashida added the text, "to accomplish the aim of the preceding paragraph." The amendment by Ashida was justification for the government to keep its minimum ability to defend itself with a Self-Defense Force.

The Abe Cabinet decision of 2014 changed the public interpretation and endorsed the power of self-defense as a right of sovereignty in the famous Sunagawa case. Most of Anzo Suzuki's students argued that the word "renounce" in Paragraph 1 of Article 9 meant all war was waived. Wars occurred in history in order to solve international disputes. Yasuo Hasebe proposed another interpretation that follows the pre-2014 public interpretation put forth by the CLB. The majority of Japanese constitutional law scholars are against the cabinet decision of 2014 to endorse collective defense power without an amendment of the constitution (Kaishaku Kaiken). It seems they believe that several patterns of attack can be addressed by individual defense power alone.

The drafting history shows that there was not strong pressure for a special tribunal to preside over the constitutional law court during negotiations between Japan and the U.S. The term "temporary veto power" in SWNCC-228 meant that the legislative body was to be strong. The discussion concluded that giving veto power to the Supreme Court to review legislation without the existence of a concrete dispute was against SWNCC-283 and the Supreme Court was on able to resolve constitutional interpretation issues in concrete disputes over the power of the legislative body. Whether the phrase case and controversy or disputes on law was identical was left for the next generation of Japanese constitutional law scholars. Unlike in the U.S. Constitution, judicial review was stipulated in Article 81 of the Japanese Constitution but the details regarding case and controversy were not included. Details regarding disputes on law are only included in the Japanese Court Act.

If we take the National Police Reserve decision and the core of judicial power

154 John Maki, The Constitution of Japan: Pacifism, Popular Sovereignty, and Fundamental Human Rights, JAPANESE CONSTITUTIONAL LAW, supra note 42 at 53.

Lawrence Beer, The Constitution of Japan, DANIEL FOOTE, LAW IN JAPAN 263 (Asian Law Series 2007). "Should there come a time for amendment, Japan might seriously consider adding a third paragraph to Article 9, forever renouncing the development, manufacture, possession, introduction $\cdots$ or use of nuclear, chemical $\cdots$ weapons of mass destruction. Might not Japan then credibly urge others to do likewise? Any progress in that direction would be victory for humankind." 
seriously, it would be unconstitutional to establish a constitutional tribunal with abstract judicial review powers independent of the regular hierarchy of the judiciary. This would overturns important constitutional precedent. Parliament even discussed a proposal to amend the Court Act to delete the phrase "disputes on law" and to add a new procedure for abstract judicial review in time of the National Police Reserve decision.

The Nagoya high court has the advantage that the judiciary maintains its authority and power of judicial review and encourages the legislature to review statutes regarding Article 9. The court held there was no infringement on the right to live in peace but it recognized this right through legal norms.

Japanese constitutional law scholars must study not only Article 9 but intra-factional conflicts within the political party as well and review if the leader of the political party reflects the will of the voters. Japanese constitutional studies should focus on cabinet leadership because the Meiji government lost control as a result of interference from the military in events such as the 226 coup d'État (the February 26 incident) in 1936.

Cabinet meetings are not stipulated in the Japanese Constitution. Decision-making is autonomous and beyond judicial review. Unfortunately, the judiciary is only a passive branch. It avoids unnecessary political disputes and it cannot review its autonomy through cabinet meetings or committee deliberations. However, there might be room for it to review issues such as the infringement of human rights.

In 2014, the Abe Administration created three new conditions to make defense power permissible under Article 9. First, an attack on Japan must occur, a nation in a close relationship with Japan must be attacked, the existence of the Japanese nation must be endangered, or it must be clear that life, liberty, and the right to the pursuit of happiness is threatened. Second, there must be no alternative measures to preventing the attack, preserving the nation, or protecting the people. Third, its exercise must meet the necessary minimum requirements.

This likely refers to an armed attack against a foreign country resulting in a threat to Japan's survival. The Abe Cabinet's goals are to permit the SDF to dispose of underwater mines in the Strait of Hormuz, to intercept missiles targeting the U.S., and to search and inspect suspected ships. It is not clear how the government will address general economic crises. 
The SDF may carry fuel, conduct aerial refueling, transport goods to the U.S. army, clean up interferences in the South China Sea, and maintain sea lanes. The opposition party complained that this logistical support raises the risk of wars where the Japanese SDF may be involved.

The most important changes were the removal of the limitation of an exclusively defensive security policy known as Senshu Bouei and geographic limits. SDF activities are controlled by parliament and the degree of control varies under ten defense and peace statutes enacted in 2015. These statutes show how the representative legislature controls the cabinet and the supreme commander of the SDF as well as the prime minister through the use of the Japanese Constitution.

By citing statements made by members of the Diet, Ohishi argues that the CLB endorsed the existence of collective defense power but denied the exercise thereof. He stated that the CLB should show persuasive grounds for collective defense power well before 2014.

Fujita states that the 2014 cabinet decision was an irrational political action and constitutional law scholars expressed strong criticism against the Abe Cabinet. He regrets that the majority of public law professors have not made consistent sophisticated analyses.

According to Inoue, exclusively defensive security policy known as Senshu Bouei was the subject of a constitutional amendment without using amendment procedures (Kaishaku Kaiken). Hasebe and Inoue argue that by changing the public interpretation of the constitution without using formal amendment procedures (Kaishaku Kaiken), the core of constitutionalism was circumvented.

Both Inoue and Hasebe may try to address the reality of an unconstitutional state of affairs in Japan. By deleting Article 9, Inoue argues that the government must maintain continuous discussions on defense and security under a normal legislative process.

Hajime Yamamoto argues that it is possible to change the constitutional interpretation to endorse collective defense power without amending the constitution. He denies the qualifications of the Abe Cabinet to change constitutional interpretation. It is nonsense for Yamamoto to ask bureaucrats in the CLB to preserve one interpretation of the constitution.

Mizushima argues that Article 9 text barely permits individual defense power. The constitution permits individual defense power as long as no alternative measure exists. Pre- 
2014 official interpretation permits narrower individual defense power than the power permitted by international law.

Article 9 as well as other notions such as legislative control over the cabinet, the civilian clause, special military tribunals, autonomy of other governmental branches under judiciary review, and sovereignty should be reviewed. Japanese constitutional scholars in Japan should bridge the gap between constitutional law texts and people's understanding and talk with other scholars and governmental officials about defense and security issues in international deliberations. This supports the goal of the rule of law in Japan to maintain universal values in its constitution.

(Associate Professor, Graduate School of Humanities and Social Sciences) 